\title{
DESIGN AND DEVELOPMENT OF EARLY HEAT STROKE DETECTION SYSTEM IN MILITARY CROSS COUNTRY BASED ON IOT
}

\author{
Iksan Jaya, Edy Maryanto, Alexander Victor Bukit, Muhamad Zulkifli \\ D-3 Teknik Informatika, Sekolah Tinggi Teknologi Angkatan Laut, \\ www.sttal.ac.id
}

\begin{abstract}
ABSTRAC
Cross-country military sports are sports that are contested in the military environment as an effort to foster the physical abilities of the Navy's soldiers. The doctrine in the Indonesian Navy forcefully demands every soldier to never give up in every task that is carried out so that in military sporting events the soldier will spend all of his abilities. In the process of cross-country competition with heavy physical activity causing many soldiers who experience heat exhaust (pre heat stroke conditions) continue to force themselves to compete and will continue to become a heat stroke. This is compounded by the distance traveled so that the medical team had difficulty reaching the soldiers who experienced the incident. Internet of things (IOT) is the idea that all objects in the real world can communicate with each other as part of an integrated system using the internet network as a link.

By using the loT platform it is possible to monitor an object continuously and provide analysis directly without being limited by distance and time. Based on the description above, it is necessary to design and build an early detection system for the heat stroke of TNI AL soldiers in cross-country military sport activities based on loT (Internet of Thing). This system can help detect positions and soldiers who will experience heat stroke so that medical treatment can be given early to prevent heat stroke.
\end{abstract}

Keywords: Monitoring, Heat Stroke, Cross Country, loT.

\section{INTRODUCTION}

Military sports are sports that are specifically contested in the military environment as an effort to foster the physical abilities of soldiers. Military sports activities are carried out gradually and continuously with the aim of physically developing soldiers to be ready to carry out the tasks assigned. There are various kinds of matches in military sports but the Navy Marine Corps environment generally matches five sports, namely cross country, speed march, military swimming, shooting and obstacle course. In military sports matches each soldier uses a full military uniform plus weapons, magasen and pack equipment with a weight of about $15 \mathrm{~kg}$. The implementation of military sports, especially cross-country sports, is carried out in the open, bumpy, uphill and exposed to direct sunlight. The distance of cross country matches as far as $12 \mathrm{~km}$ with a travel time between 2 to 3 hours, this condition causes many soldiers who are exhausted and dehydrated experiencing heat exhaust (heat exhaustion). When the heat exhaust conditions athlete's body temperature reaches $39^{\circ} \mathrm{C}$ and if not treated quickly it can cause heat stroke (heat stroke).

The doctrine in the Indonesian Navy forcefully demands every soldier to never give up in every task that is carried out so that in military sporting events the soldier will spend all of his abilities. In the process of cross-country matches with heavy physical activity causing many soldiers who experience heat exhaust (pre-heat stroke conditions) continue to force themselves to compete and will continue to be a heat stroke which is a case of emergency. This is exacerbated by the distance traveled so that the medical team has difficulty reaching soldiers who experienced the incident, often because of the delay in handling from the medical team the heat stroke incident can 
cause permanent damage to organs and even death.

Based on the description above, it is necessary to design and build an early detection system for the heat stroke of TNI AL soldiers in cross-country military sport activities based on loT (Internet of Thing). This system can help detect positions and soldiers who will experience heat stroke so that medical treatment can be given early to prevent heat stroke.

Based on the background description of the problem above, then the problem can be formulated, namely how to design and build an early heat stroke detection system for Indonesian Navy soldiers in cross country military sport activities based on loT ?

The purpose of this research is to design an early detection system of heat stroke of the Indonesian Navy soldiers in cross country loT-based military sports activities. This system can help detect the occurrence of pre heat stroke (heat exhaust) in soldiers who are carrying out cross-country military sports and can accurately determine the position of soldiers who experience incidents quickly so that it will facilitate the competition committee in supervising and providing a sense of security to cross country athletes, so that no more soldiers were found who forced themselves to continue carrying out cross-country military sports activities even though the signs of pre-heat stroke had been found. follows:

The benefits of this research are as

a. For the Committee:

1) Simplify the process of identifying soldiers who will experience a heat stroke.

2) Facilitate supervision of crosscountry military sports athletes due to the monitoring of body temperature and athlete position.

3) Reducing the incidence of servicemen who suffered heat strokes during cross country matches.

b. For the Medical Team:

1) Simplify efforts to prevent / prevent heat stroke in cross-country military sports athletes. Make it easier to find out the position of athletes accurately who experience the events of pre heat stroke so that medical treatment can be more effective.
1) Facilitate medical treatment in accordance with the conditions of athletes who will experience a heat stroke.

c. For Military Sports Athletes:

1) Reducing the anxiety of having a heat stroke during military sports activities due to the early warning system.

2) Convincing the TNI AL soldiers that what has been done in a military sports match is the maximum capability they have.

3) Make it easier to know personal abilities so that they do not force themselves outside the limits of ability as proof of unyielding souls for reasons of stopping in a match with accurate scientific data.

\section{LITERATURE REVIEW \\ 2.1. System}

Edhy Susanta S.T (2003), the system can generally be defined as a group of things or something that is connected in a certain way so as to form a single unit to carry out certain functions in order to achieve certain goals in accordance with what has been planned.

\subsection{Heat Stroke}

Dr. Indra K. Muhtadi (2016), heat exhaust is a condition when the body becomes too hot due to the failure of the cooling mechanism in the body to maintain the normal core temperature of the body (body core temperature). If the heat exhaust condition is not corrected and continues, it will develop into a heat stroke which is a case of emergency.

Heat stroke is a condition that can be fatal, which occurs due to exposure to heat for a very long time, where the patient can not sweat enough to lower his body temperature. If not treated immediately, heat stroke can cause permanent organ damage or death. A temperature of $40^{\circ}$ Celsius is very serious, one degree above is often fatal. Permanent damage to internal organs, for example the brain can happen immediately and often ends in death. 


\subsection{Cross Country Military Sports}

Cross-country military sports (crosscountry running) according to the world athletic organization International Association of Athletics Federations (IAAF) is a type of distance running sport with a distance of 12 $\mathrm{km}$ where the assessment is done by taking time for individual participants and team participants by adding up the values each team member. If there is the same value, then it is determined by the last runner of the team whose value is the same as the runner who entered the finish earlier.

This sport was later adopted and contested in the military because cross country can train physical and mental soldiers in extreme fields with almost the same rules as the rules of the IAAF world athletic organization, which differ only in terms of uniforms and the burden of backpacks and weapons carried by each each cross country athlete.

\subsection{Internet of Things}

Wikipedia (2017), Internet of Things or also known by the abbreviation loT, is a concept that aims to expand the benefits of internet connectivity that is connected continuously. Internet of things is the idea that all objects in the real world can communicate with one another as part of a unified integrated system using the internet network as a link, for example CCTV installed along the road is connected to the internet connection and integrated in the control room which may be tens of distances kilometer or a smart home that can be managed via a smartphone with the help of an internet connection.

Three important components that must be present in an IoT device are sensors, connectivity and control. Sensors are needed by an loT device to be able to capture a natural phenomenon, such as temperature, pressure, vibration, sound, light, etc., while connectivity is needed so that the device can communicate with other devices. Control becomes a major part of the loT device that connects storage and retrieval of sensor monitoring data, so that it can read sensor values, send and receive data to and from storage media and also a series of responses based on the data obtained.

\subsection{Wemos D1 Mini}

The Wemos D1 Mini Wifi Module is a board module that can function with Arduino specifically for projects that carry the loT concept. Wemos can run stand alone without the need to be connected to a microcontroller, in contrast to other $\mathrm{WiFi}$ modules that still need a microcontroller as a controller or the brain of the circuit, wemos can run stand alone because there is already a CPU that can program via a serial port or via OTA and transfer programs wirelessly.

Wemos has 2 chipsets that are used as brain work, among others.

\section{a. ESP8266 Chipset}

ESP8266 is a chip that has wifi features and supports the TCP / IP stack. This small module allows a microcontroller to connect to a WiFi network and make TCP / IP connections using only a simple command. With an $80 \mathrm{MHz}$ clock the chip is equipped with $4 \mathrm{MB}$ of external RAM and supports the IEEE $802.11 \mathrm{~b} /$ $\mathrm{g} / \mathrm{n}$ format so that it does not cause interference for others.

\section{b. $\mathrm{CH} 340$ Chipset}

$\mathrm{CH} 340$ is a chipset that converts a USB serial into a serial interface, for example the converter to IrDA application or the USB converter to printer application. In serial interface mode, the $\mathrm{CH} 340$ sends the connecting signal commonly used on modems. $\mathrm{CH} 340$ is used to change a common serial interface device to connect to the USB bus directly.

\subsection{DS18B20 Temperature Sensor}

According to Septiawan (2013), a sensor is a device to detect / measure something, which is used to convert mechanical, magnetic, heat, light and chemical variations into voltage and electric current. In the control and robotics system environment, sensors provide similarities that resemble the eyes, hearing, nose, tongue which will then be processed by the controller as the brain. This heat stroke detector uses a body temperature sensor DS18B20.

The DS18B20 sensor is a digital temperature sensor manufactured by MAXIM Integrated in which there is an ADC (Analog to Digital Converter) with a 12-bit resolution. 
This sensor has a fairly high accuracy rate of $\pm 0.5^{\circ} \mathrm{C}$ in the temperature range of $-10^{\circ} \mathrm{C}$ to $+85^{\circ} \mathrm{C}$ and overall can measure temperatures from $-55^{\circ} \mathrm{C}$ to $+125^{\circ} \mathrm{C}$.

\subsection{System Planning}

Andri Kristanto (2003), systems analyst has several meanings, including:

a. Someone who has the ability to analyze a system. The analyst includes studying the problems that arise and determining the needs of system users.

b. Someone who has the ability to choose the most appropriate alternative solutions to problems.

c. A person who has the ability to plan and implement system designs in accordance with the problems that occur.

Andri Kristanto (2003), Systems analysis has the following tasks:

a. Collecting and analyzing all documents, files, forms used on the system that is already running.

b. Compile a report of the system that is already running and evaluating the deficiencies that exist in the system that is already running.

c. Design improvements to the system and develop a new system.

d. Analyze and prepare estimates of the costs needed for a new system and provide arguments about the benefits of using a new system.

e. Oversee all existing activities, especially those related to the application of the new system.

At the design stage, problem identification and analysis are carried out to determine the factors that are problems in the existing system or use. Data from external sources (system users) are collected as material for analysis. If all problems have been identified, proceed with studying and understanding the workflow of the system used. The next step is to analyze and compare the system that will be formed with the previous system and then make a report.

\section{RESEARCH METHODS}

\subsection{Types of research}

This type of research is applied research in which this research is conducted to provide practical solutions to certain problems. However, this research can also be categorized as engineering research because applying science into a design in order to get performance in accordance with specified requirements. The design is a synthesis of design elements combined with scientific methods into a system that meets certain specifications. The research is directed to prove that the design meets the specified specifications. The research starts from determining the design specifications that meet predetermined specifications, choosing the best alternative, and proving that the design chosen can meet the specified requirements in an efficient, effective and low-cost manner.

\subsection{Time and Place of Research}

The time of the final assignment research is from August 2017 to November 2017, while the place for conducting crosscountry military sports research is conducted at the 5th Marine Infantry Battalion (Battalion - 5 Mar) Surabaya and the Cilandak Marine Hospital (RSMC).

\subsection{Research Tools and Materials}

The tools and materials needed in conducting the research include:

a. Android smartphone is used as a sender of sensor signals to the web server, also as a marker of the athlete's position in the Google map map and as a provider of power supplies for the WiFi module board.

b. The Wemos D1 Mini wifi module board is used as a reader and processor of the sensor data that has been obtained and then sent in realtime to the webserver via the internet network.

c. The DS18B20 body temperature sensor is used as a measure of the body temperature of athletes who carry out cross-country matches. 
d. Android gps logger application, used as a gps data sending software to the webserver.

e. Sublime Text is used as a text editor to write PHP programs. Sublime text used is sublime text version 3 . The PHP version used in this program is PHP version 5.6.3

f. Bootstrap software is used to make responsive web pages so that the appearance of web pages becomes more attractive. g. Mysql Database Software is used as a database management system processor.

h. Domain and Hosting is used as a web address and a place to store PHP data files and databases in the int network.

i. Personal Computer (PC) is used as a heat stroke monitoring display during cross country matches.

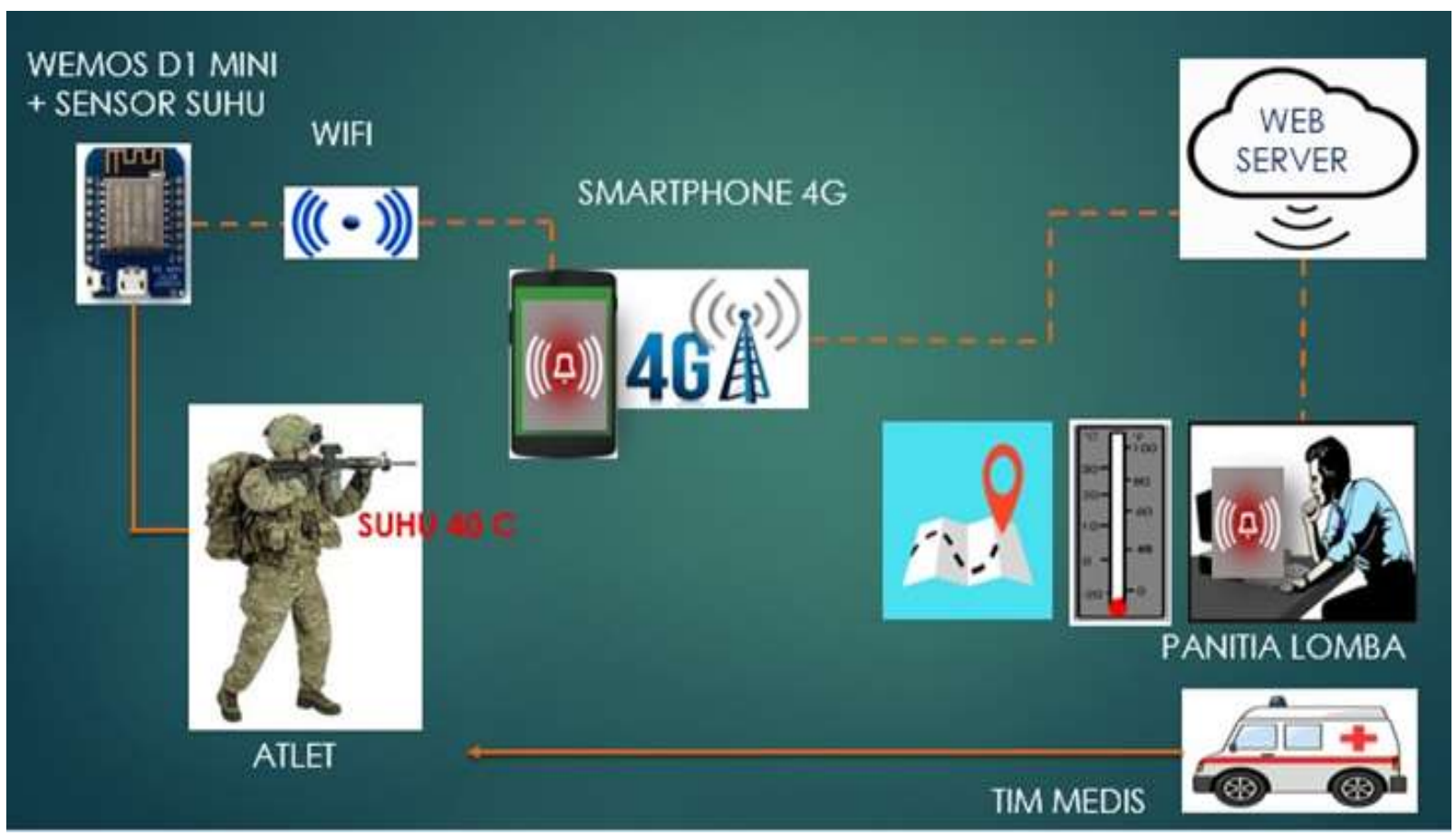

Figure 1 : System Description

\section{RESEARCH DESIGN}

The research design is a stage to provide an overview of the system that will be created. Starting from analyzing the system is the stage of studying the existing system based on the results of a survey of existing problems. Then various survey data are processed to get a general picture of the results obtained. Heat stroke detector equipment is given to each athlete in accordance with the data of each athlete. Next the cross country team is prepared at the starting point to start the match. In the process of competition if the athlete's body temperature reaches 39 degrees, the system will give an alarm in the form of an alarm to athletes and the committee. Athletes who receive heat stroke alarms are obliged to stop competing, the committee that gets a warning alarm then detects the athlete's position via the athlete's smartphone gps, then sends a health team to provide medical assistance to athletes who are almost experiencing heat exaust (pre heat stroke). 


\section{Context Diagram}

In making this system, a design is made using Context diagrams. The context diagram in the figure illustrates the system in outline of all the relationships that exist in the early heat stroke detection system in cross country military sport for the Navy.

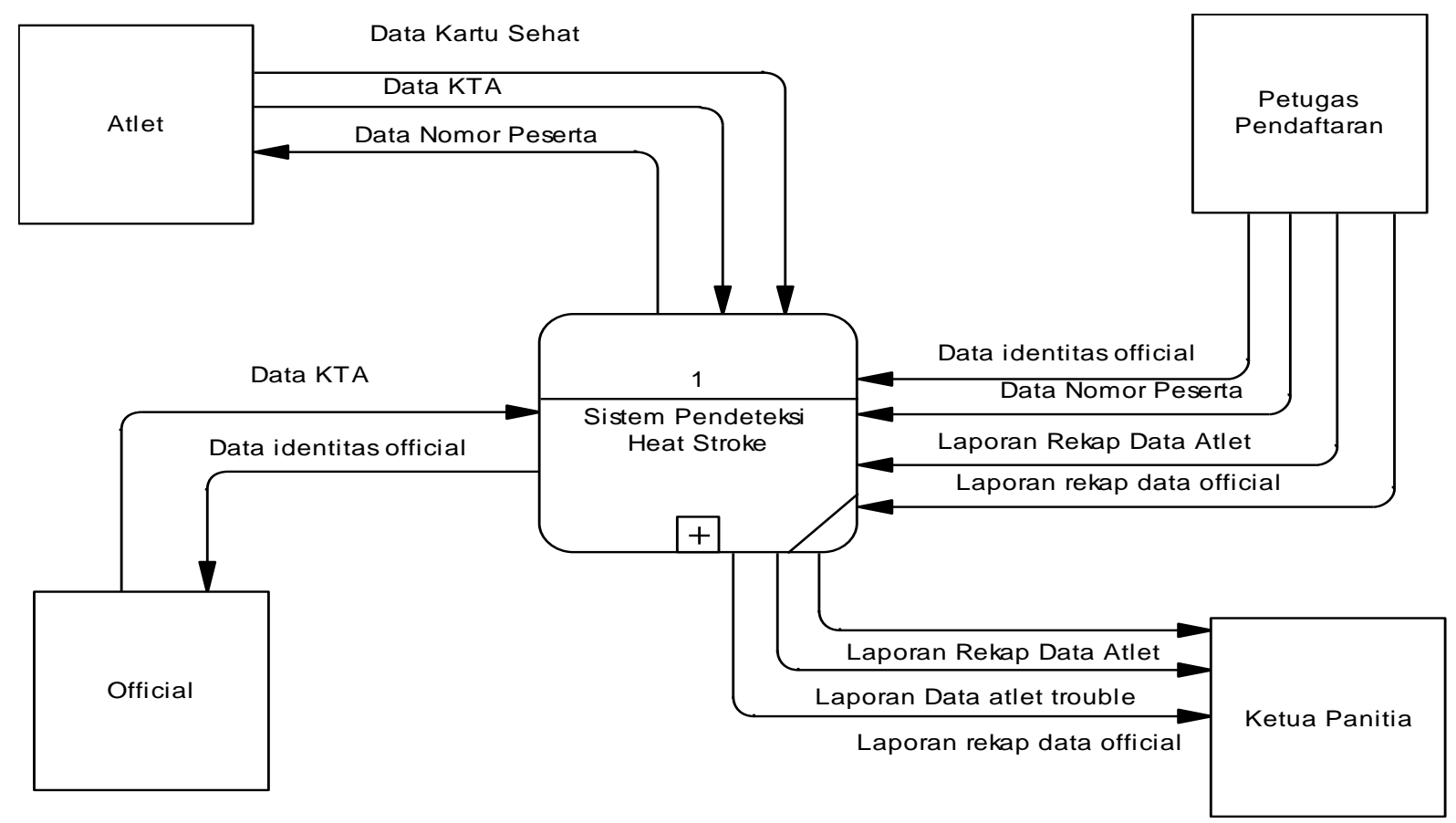

Figure 2 : Flow Diagram System

\subsection{Data Flow Diagrams (DFD)}

Data Flow Diagrams (DFD) are data flow diagrams that illustrate a new system that will be developed logically, without considering the physical environment in which the data flows or is stored. In this diagram using certain symbols that aim to facilitate reading and understanding to analyze a system. DFD level 0 early detection system for heat stroke. 


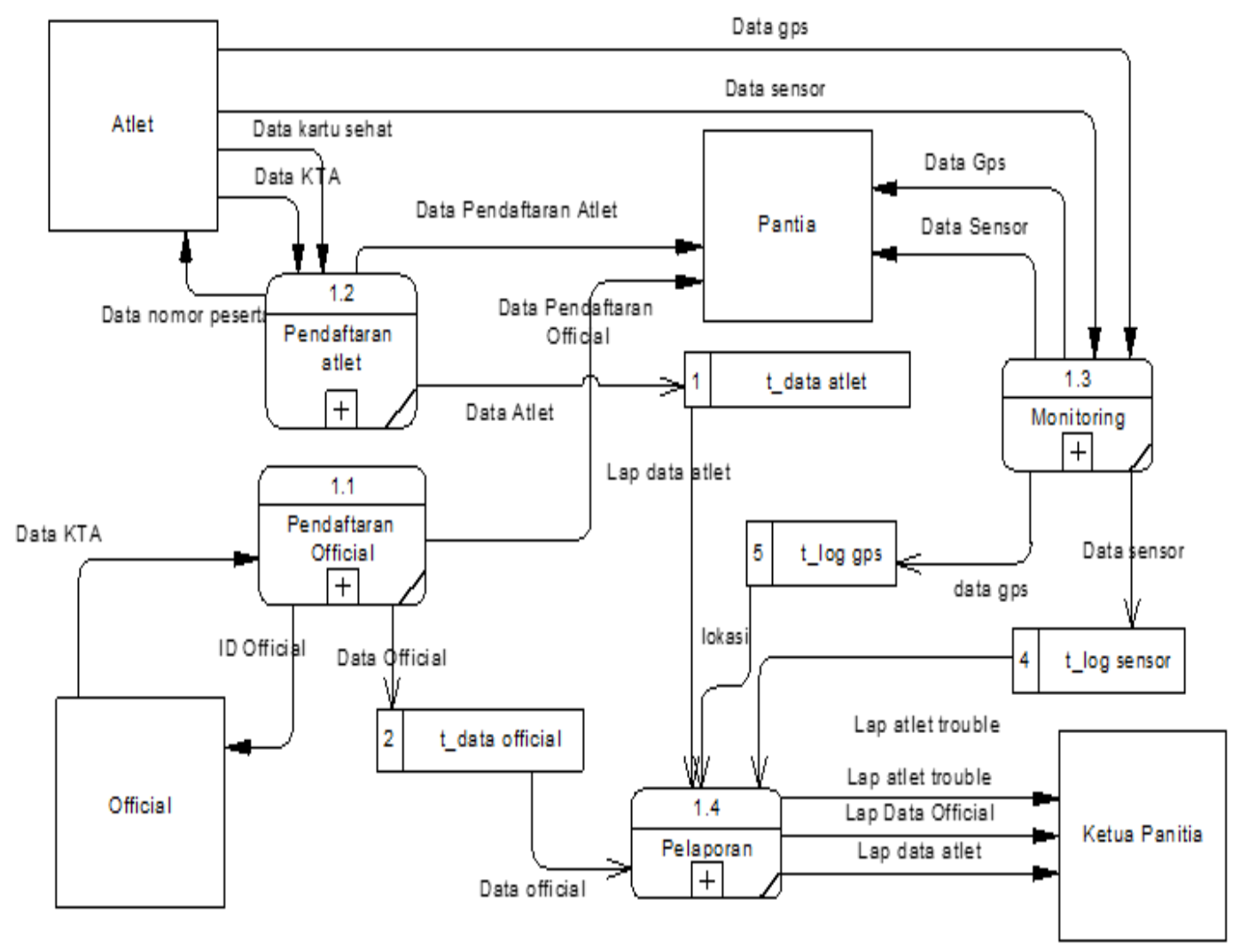

Figure 3 : DFD Level 0

DFD level 0 , there are four processes namely official registration, athlete registration, monitoring and reporting. In these processes there are sub-processes of each of the existing processes. In Figure 3 there are several entities, namely Official, Athlete, Registration Officer and Committee Chairperson. For tables consisting of t data_atlet tables, t_data_official tables, t_log_sensor tables and t_log_gps tables.

\subsection{Physical Data Model}

Physical Data Model (PDM) in the early heat stroke detection system for Navy soldiers in cross-country military sports is obtained from the conceptual data model (CDM) that illustrates various tables in the system that contain relationships from each table involved in the heat stroke early detection system and is equipped with table attributes along with related table key attribute attributes obtained from generating relations from conceptual data models. The PDM that has been created will then be converted automatically into a database of early detection of the heat stroke of the Indonesian Navy in cross-country military sports. 


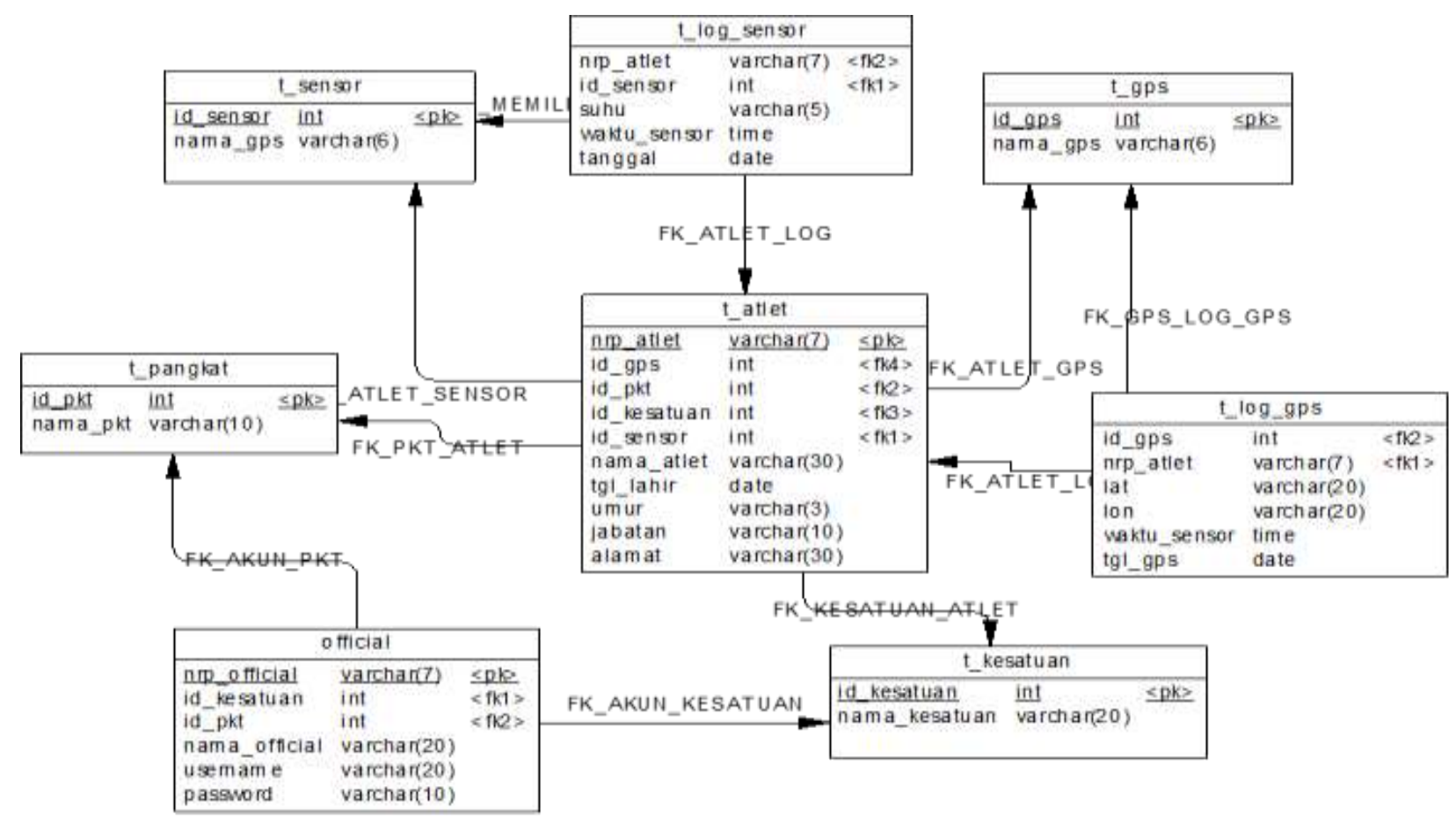

Figure 4 : Physical Data Model

\subsection{Data collection}

Data collection method is a method used to find out what and how the required data can be collected so that the final results of the study are able to present valid and reliable information. Data collection methods used in this thesis are the method of observation, interview and literature study.

The method of observation is a method of collecting data which is done by direct observation of data related to this study while the interview method is a method of collecting data conducted by way of direct question and answer

heat stroke and is equipped with table attributes along with related table key attribute attributes obtained from the generated relation of the conceptual data model.

The PDM that has been created will then be converted automatically into a database of early detection of the heat stroke of the Indonesian Navy in cross-country military sports.

To the speakers related to the data needed in this study. In the process of collecting research data, the authors observed data on heat stroke cases in crosscountry military sports at Cilandak Marine Hospital (RSMC) Jakarta and conducted interviews with cross-country athletes Yonif 5 Marines of Surabaya. Furthermore, the authors conducted a literature study conducted by finding references from books, journals and internet media related to heat stroke in military sports.

\subsection{Data processing}

Data processing techniques performed in this thesis has several stages, namely:

a. Reference data collection is done by searching

references related to the problems discussed in this thesis,

that is data about heat stroke and cases of heat stroke that have occurred in cross country matches within the Indonesian Navy, while hardware references include the Wemos D1 Mini wifi module board and body temperature sensors and the use of the google map application.

b. Making the design of programs and hardware in this process 
algorithm will be made, flowchart and series based on the references obtained.

c. Processing of body temperature data that has been collected from several athletes using an early heat stroke detection tool that has been made. The trial is done by evaluating and testing the functions contained in the system. When an error is found, it will be repaired and then reevaluated or tested until the application does not experience an error.

\subsection{Operational definition}

Operational definitions in research are elements of research related to the variables contained in the research title or included in the research paradigm in accordance with the results of the problem formulation. Theory

this is used as a basis or reason why something related can affect independent variables or is one of the causes. Operational definitions in research are elements research that provides information on how to measure a variable in this study, namely:

a. The level of accuracy of the system in detecting shu body athletes who carry out cross country matches, is one of the very important variables in the early heat stroke detection system, using a DS18B20 body temperature sensor with a high degree of accuracy.

b. The speed of sending data to a web server in a web programming based system is very much considered, therefore the use of a $4 \mathrm{G}$ network is expected to accelerate the work process of the system.

\section{RESULTS AND DISCUSSION 5.1. Software Testing}

Software testing is carried out to determine the extent of work capability of the software system testing consisting of the sensor reading process, the body temperature sensor sending process, the process of retrieving and sending gps data, the login process, the logout process, the input process, the monitoring process, the search process and the logout process. The overall software testing can be seen the results in table 1.

software for early detection of heat strokes of Navy personnel on cross country military sports.

\subsection{Hardware Testing}

Hardware testing is carried out to determine the extent to which the work capabilities of the hardware installed on the early heat stroke soldier system of the Indonesian Navy in loT-based cross-country military sports.

Hardware testing conducted on this system is testing the process of detecting body temperature from the sensor by the wifi module Wemos D1 Mini and testing the ability to lock the GPS position of an Android smartphone.

Testing the process of detecting body temperature is carried out to determine the extent of the sensor's ability to read the athlete's body temperature with the best level of accuracy. Testing is done by placing the DS18B20 sensor in the arm and armpits of athletes.

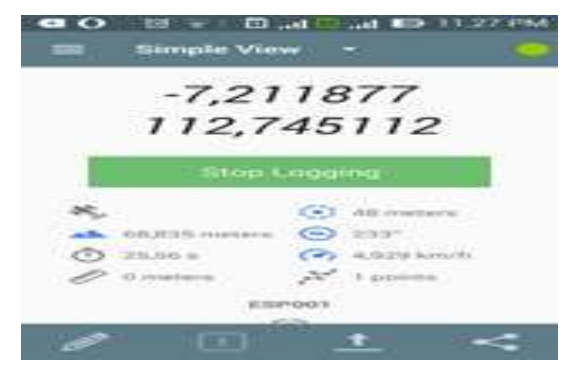

Figure 5 : Log Data GPS 
Tabel 1. Software Testing

\begin{tabular}{|c|c|c|c|c|c|c|}
\hline NO & PROGRAM & TARGET & INPUT & IDEAL OUTPUT & OUTPUT & $\begin{array}{c}\text { STATU } \\
S\end{array}$ \\
\hline 1 & 2 & 3 & 4 & 5 & 6 & 7 \\
\hline 1. & LOGIN & Enter program & $\begin{array}{l}\text { Username } \\
\text { Password }\end{array}$ & Enter Program & Enter Program & Valid \\
\hline 2. & $\begin{array}{l}\text { READ } \\
\text { CENSOR }\end{array}$ & Read temp & Temp & Read Temp & Temp Acquired & Valid \\
\hline 3. & $\begin{array}{l}\text { LOG DATA } \\
\text { GPS }\end{array}$ & Lock data gps & $\begin{array}{l}\text { Data gps } \\
\text { smartphone }\end{array}$ & Read Data gps & $\begin{array}{l}\text { Data gps } \\
\text { aquired }\end{array}$ & Valid \\
\hline 4. & $\begin{array}{l}\text { SEND DATA } \\
\text { CENSOR }\end{array}$ & $\begin{array}{l}\text { Send to } \\
\text { database }\end{array}$ & Temp & $\begin{array}{l}\text { Temp send to } \\
\text { Database }\end{array}$ & $\begin{array}{l}\text { Temp send to } \\
\text { Database }\end{array}$ & Valid \\
\hline 5. & $\begin{array}{l}\text { SEND LOG } \\
\text { DATA GPS }\end{array}$ & Send data gps & $\begin{array}{l}\text { Data gps } \\
\text { smartphone }\end{array}$ & $\begin{array}{l}\text { Temp send to } \\
\text { Database }\end{array}$ & $\begin{array}{l}\text { Temp send to } \\
\text { Database }\end{array}$ & Valid \\
\hline 6. & $\begin{array}{l}\text { INPUT DATA } \\
\text { PERSONEL }\end{array}$ & Entry data & $\begin{array}{l}\text { Data } \\
\text { Personel }\end{array}$ & $\begin{array}{l}\text { Data enter to } \\
\text { database }\end{array}$ & $\begin{array}{l}\text { Data enter to } \\
\text { database }\end{array}$ & Valid \\
\hline 7. & $\begin{array}{l}\text { INPUT DATA } \\
\text { OFFICIAL }\end{array}$ & $\begin{array}{l}\text { Entry official } \\
\text { data }\end{array}$ & Data Offcial & $\begin{array}{l}\text { Data enter to } \\
\text { database }\end{array}$ & $\begin{array}{l}\text { Data enter to } \\
\text { database }\end{array}$ & Valid \\
\hline 8. & MONITORING & Monitoring & $\begin{array}{l}\text { If temp }= \\
39^{\circ} \mathrm{C}\end{array}$ & Alarm on & Alarm on & Valid \\
\hline 9. & LOGOUT & Exit Program & Sign out & Back to login & Back to login & Valid \\
\hline $\begin{array}{c}10 \\
.\end{array}$ & $\begin{array}{l}\text { DISPLAY } \\
\text { DATA } \\
\text { PERSONEL }\end{array}$ & $\begin{array}{l}\text { Display data } \\
\text { Personnel }\end{array}$ & & $\begin{array}{l}\text { Display data } \\
\text { Personnel }\end{array}$ & $\begin{array}{l}\text { Display data } \\
\text { Personnel }\end{array}$ & Valid \\
\hline $\begin{array}{c}11 \\
\cdot\end{array}$ & $\begin{array}{l}\text { DISPLAY } \\
\text { DATA } \\
\text { OFFICIAL }\end{array}$ & $\begin{array}{l}\text { Display data } \\
\text { Official }\end{array}$ & & $\begin{array}{l}\text { Display data } \\
\text { Official }\end{array}$ & $\begin{array}{l}\text { Display data } \\
\text { Official }\end{array}$ & Valid \\
\hline $\begin{array}{c}12 \\
.\end{array}$ & $\begin{array}{l}\text { DISPLAY } \\
\text { DATA } \\
\text { GALERY }\end{array}$ & $\begin{array}{l}\text { Display data } \\
\text { Personnel } \\
\text { galeri }\end{array}$ & & $\begin{array}{l}\text { Display data } \\
\text { Personnel galeri }\end{array}$ & $\begin{array}{l}\text { Display data } \\
\text { Personnel galeri }\end{array}$ & Valid \\
\hline
\end{tabular}


Table 2. GPS Log Testing

\begin{tabular}{|c|l|c|c|}
\hline No & Smartphone & Kondisi & Gps \\
\hline 1. & Zenfone C & Walk & Valid \\
\hline 2. & Zenfone 4 & Walk & Valid \\
\hline 3. & $\begin{array}{l}\text { Samsung } \\
\text { Galaxy }\end{array}$ & Walk & Valid \\
\hline 4. & Zenfone C & Run & Valid \\
\hline 5. & Zenfone 4 & Run & Valid \\
\hline 6. & $\begin{array}{l}\text { Samsung } \\
\text { Galaxy }\end{array}$ & Run & Valid \\
\hline
\end{tabular}

The results and discussion of the athlete's location locking (gps log) testing process is the part that explains the results of the log data by an android smartphone. Based on the table, it can be concluded that the ability to lock the three types of android smartphone above is the same both in running and running conditions.

\section{CONCLUSIONS AND RECOMMENDATIONS}

\subsection{Conclusion}

Based on the results of tests that have been carried out on the design and construction of an early detection system of heat strokes of the Indonesian Navy troops on loT-based cross country military sports, the following conclusions are obtained:

a. Can display the athlete's body temperature in real time

b. so that it can detect soldiers who will experience a heat stroke.

c. Can find out the position of athletes who experience heat stroke incidents quickly and precisely so that medical treatment can be more effective.

d. Can quickly display and search cross country athlete data.

e. Can provide a warning warning of heat stroke danger to the committee and athletes, so that the reasons athletes stop competing have logical and scientific reasons.

\subsection{Recomendation}

Recomendation for system development are as follows:

a. In this system a heart sensor can be added so that the detection process refers to more than one parameter, namely body temperature and heart rate. b. In this system, it can be uploaded to hosting with unlimited bandwidth, so that it can be accessed by all soldiers without worrying about a decline in server data traffic.

c. In this system a better security system can be added, so the chances of being corrupted by hackers are smaller.

\section{REFERENCES}

Ahmadi, Umar Fahmi, dkk. (1990). Upaya Kesehatan Kerja Sektor Informal di Indonesia. Jakarta: Departemen Kesehatan Republik Indonesia.

Connolly, Thomas and Begg, Carolyn. (2010). Database Systems: A Practical Approach to Design, Implementation,

and Management, Fifth Edition. Boston: Pearson Education.

Febrian, J, (2008) Menjelajah Dunia dengan Google, Mesin Pencarian Informasi di Internet Terbesar di Dunia. Bandung: Informatika.

Hidayatullah, Priyanto dan Kawistara, Jauhari kairul. (2014). Pemrograman Web. Bandung: Informatika

Kristanto, Andi. (2003). Analisis dan Desain Sistem Informasi. Yogyakarta: Graha IImu.

Mustakini, Jogiyanto Hartono. (2009). Sistem Teknologi Informasi (Edisi III). Andi . Yogyakarta.

Prihatna, H. (2005). Kiat Praktis Menjadi Webmaster Profesional. Jakarta: Elex Media Komputindo.

Rozi, Zaenal A. dan SmitDev Community. (2015). Bootstrap Design Framework. Jakarta: Elex Media Komputindo.

Sutanta, Edhy. (2011). Basis Data dalam Tinjauan Konseptual.

Andi. Yogyakarta.

Waljiyanto. (2003). Sistem Basis Data: Analisis dan Pemodelan Data. Yogyakarta: Graha IImu. 